\title{
IMPACT OF WATER LEVEL FLUCTUATION IN THE SHAPING OF ZOOPLANKTON ASSEMBLAGE IN A SHALLOW LAKE
}

\author{
Maria Špoljar ${ }^{1 *}$, Tvrtko Dražina ${ }^{1}$, Jasna Lajtner ${ }^{1}$, Goran Kovačevič ${ }^{1}$, Ana Pestić ${ }^{1}$, Dora \\ Matijašec ${ }^{2}$, Tea Tomljanovi ${ }^{3}$
}

'Department of Biology, Division of Zoology, Faculty of Science, University of Zagreb, Rooseveltov trg 6, HR-10 000 Zagreb, Croatia

${ }^{2}$ Department of General and Inorganic Chemistry, Faculty of Chemical Engineering and Technology, University of Zagreb, Marulićev trg 20, HR-10000 Zagreb, Croatia

${ }^{3}$ Department of Fisheries, Beekeeping, Game Management and Special Zoology, Faculty of Agriculture, University of Zagreb, Svetošimunska 25, HR-10 000 Zagreb, Croatia

*Corresponding Author, Email: maria.spoljar@biol.pmf.hr

\section{ARTICLE INFO}

Received:15 September 2017

Received in revised form: 13 November 2017

Accepted:17 November 2017

Available online: 16 November 2017

\begin{abstract}
Shallow lakes are strongly affected by global climate changes reflected in significant parameters of ecosystem deterioration, i.e. biodiversity decrease, and water turbidity. Zooplankton research in Škrčev kut oxbow lake (Krapina River watershed, NW Croatia, Europe) was conducted during the summer of 2012 and 2013 with the aim to determine the effect of interannual, short-timescale changes of hydrological regime on environmental conditions, macrophytes, zooplankton and fish assemblage within an oxbow lake in the temperate region. Within one-year period the water level increased by 2 meters. This caused a significant reduction of floatingleaved macrophytes (i.e. Nuphar lutea), while turbidity, ortho-phosphate and chlorophyll a concentrations increased. These altered ecological conditions were reflected in the shift from floating-leaved macrophytes at the lower water level to phytoplankton-dominated lake at the higher water level. Zooplankton underwent significant alteration in assemblage. The results suggest that fish preference suppressed cladocerans and enhanced the rotifer and copepod abundance. Our results indicate that even in a short-timescale zooplankton assemblage mediates in the modification of ecosystem functioning.
\end{abstract}

Špoljar, M., Dražina, T., Lajtner, L., Kovačević, G., Pestić, A., Matijašec, D., Tomljanović, T. (2018): Impact of water level fluctuation in the shaping of zooplankton assemblage in a shallow lake. Croatian Journal of Fisheries, 76, 27-34. DOI: $10.2478 /$ cjf-2018-0003.

\section{INTRODUCTION}

The majority of the world's standing freshwaters are shallow (3 $\mathrm{m}$ deep or less). These water bodies are important in the view of landscape heterogeneity and have exceptional ecological significance, i.e. biodiversity, microclimate, fish spawning, birds nesting (Coops et al., 2003). Alterations in the water-level fluctuations (WLF) especially related 
to their extent, frequency and duration are among major stressors in the shallow lake ecosystems and affect alteration on nutrient concentrations, macrophyte coverage, phytoplankton biomass, zooplankton, macroinvertebrates and fish assemblage (Scheffer et al., 1993; Coops and Hosper, 2002; Kalafatić et al., 2003; Leira and Cantonati, 2008). Instabilities governed by WLF are highly expressed in (semi-)arid (Coppens et al., 2016; Echaniz and Vignatti, 2017), (sub)tropical (Meerhoff et al., 2007; Iglesias et al., 2011) and the Mediterranean region (Beklioglu et al., 2006; Castro et al., 2007; Brucet et al., 2010; Özen et al., 2010) and stressful events were caused by drought, presumably due to evaporation enhanced by global warming. On the other hand, floodplain lakes, i.e. Lake Sakadaš, in the Kopački Rit Nature park, Croatia (Galir Balkić et al., 2017) and in the Upper Paraná River floodplain, Brasil (Simões et al., 2012) are exposed to the flood pulses reassembling the whole ecosystem. Both ecosystems, in warm regions and in floodplains, including temporary water bodies, are known for their hydroperiodicity, i.e. periods of inundation and drought. In general, shallow lakes are highly susceptible to WLF caused by (local) weather conditions (high precipitation, snow melting, drought) and climate change, which affects ecology and the functioning of these lakes (Beklioglu et al., 2007).

Responses of shallow lakes to WLF could result in the shift between turbid-water without macrophytes and domination of phytoplankton, and clear-water state with submerged macrophytes (Scheffer et al., 1993). Macrophytes reduce turbidity and disappear when a critical turbidity is exceeded. This may result in habitats where floating plants or submerged plants dominate (Scheffer and van Ness, 2007). A high water level may reduce the accessible light and suppress macrophyte growth, whilst low water level may damage macrophyte stems (Leira and Cantonati, 2008). Floating macrophytes are more successful competitors for accessible light and they need high nutrient concentrations. On the contrary, submerged macrophytes are susceptible to shading, but less dependent on nutrients (Portielje and Roijackers, 1995). Macrophyte stands offer a shelter to zooplankton which controls phytoplankton biomass and keep the clear water state (Kuczyńska-Kippen, 2001; Špoljar et al., 2012; 2016). Zooplankton is incapable of controlling the phytoplankton in a nutrient-rich lake, resulting in a reduced water transparency, and zooplankton community becomes dominated by less efficient smallbodied detritivores (Beklioglu et al., 2011; Špoljar et al., 2011). During the low-water phase two scenarios could be possible. First, turbid state could be promoted by increased contact between sediment and water column and polimictic regime of shallow lakes. Second, anoxic conditions in shallow waters could lead to the risk of fish kills. This effect may be more pronounced in particular seasons (summer, winter), leading to clear water conditions (Starling et al.,
2002; Balayla et al., 2010). In this kind of environment, the functioning and biodiversity of freshwater ecosystems may be compromised by promoting the development and dominance of mats of floating plants (Scheffer and van Ness, 2007). In this study the focus was on determining the effect of inter-annual, short-time scale changes of hydrological regime on environmental conditions, macrophytes, zooplankton and fish assemblage within an oxbow lake in the temperate region.

\section{MATERIALS AND METHODS}

\section{Study site}

Our research was conducted in a shallow waterbody in North West Croatia, Škrčev kut oxbow, SK $\left(45^{\circ} 51^{-} 45^{--} \mathrm{N}\right.$, $15^{\circ} 49^{-} 29^{--}$E), covered by waterlilies Nuphar lutea (Table 1 ). SK oxbow is a separated meander of the Krapina River, isolated on the right bank from the main channel due to the construction of the highway in the 1950s.

There were high precipitations in the continental region of Croatia in the spring of 2013. Samples were collected monthly (July, August and the first half of September) during the summer of 2012 and 2013, across three habitats of transversal profile, in littoral, within the stand of macrophytes, i.e. waterlily $N$. lutea (SKm) and in pelagial (SKp).

\section{Field sampling, measurements and laboratory analyses}

For zooplankton sampling, a small boat was used to reduce the sediment resuspension. At each location, the same sampling protocol was followed: firstly, the zooplankton in the pelagial and littoral was collected, and secondly, electrofishing was performed.

Zooplankton samples were collected in triplicates with a plankton net $(26-\mu \mathrm{m})$ after filtering $3 \times 10 \mathrm{~L}$ of the water and were fixed with $4 \%$ formalin. Further analyses of zooplankton samples were described in detail by Špoljar et al. (2016). For the determination of zooplankton the following literature was used: Voigt and Koste (1978), Amoros (1984), Einsle (1993) and Streble and Krauter (2006). Ichthyofauna was sampled by electrofishing (Hans Grassl EL 63II electroshocker; 220/400 V; 17.8 / 8.9 A per 15') in the pelagial and within macrophyte stands, and their biomass $(\mathrm{g})$ and length $(\mathrm{cm})$ were measured on-site.

\section{Analyses of physico-chemical water properties}

Basic limnological parameters were measured on-site: temperature, dissolved oxygen concentration, $\mathrm{pH}$ value (Hatch 
Table 1. Main morphometric (a) and environmental (b) features (mean \pm SD) of Škrčev kut oxbow lake in 2012 and 2013 , with highlighted significant differences between researched years (Mann-Whitney $U$ test, MW test)

\begin{tabular}{|c|c|c|c|c|}
\hline Year & 2012 & 2013 & \multicolumn{2}{|c|}{ MW test } \\
\hline a) Morphometric and macrophyte features & & & $U$ & $p$ \\
\hline Length $_{\max }(\mathrm{m})$ & 300 & 336 & & \\
\hline Width $_{\text {max }}(m)$ & 12 & 14 & & \\
\hline Depth $_{\text {max }}(m)$ & 2 & 4.3 & 3.5 & 0.02 \\
\hline Macrophytes coverage (\%) & $30-40$ & $0-3$ & 0.0 & 0.005 \\
\hline Type of macrophytes & Floating-leaved & Floating-leaved & & \\
\hline Macrophyte species & Nuphar lutea & Nuphar lutea & & \\
\hline \multicolumn{5}{|l|}{ b) Environmental features } \\
\hline Transparency $_{S D}(\mathrm{~m})$ & $0.48 \pm 0.17$ & $0.43 \pm 0.11$ & & n. s. \\
\hline Turbidity (NTU) & $21.2 \pm 11.6$ & $44.6 \pm 9.2$ & 3.0 & 0.02 \\
\hline Temperature $\left({ }^{\circ} \mathrm{C}\right)$ & $25.1 \pm 4.7$ & $21.9 \pm 4.2$ & & n. s. \\
\hline Concentration of dissolved $\mathrm{O}_{2}\left(\mathrm{mgL}^{-1}\right)$ & $9.8 \pm 2.5$ & $9.0 \pm 3.1$ & & n. s. \\
\hline $\mathrm{pH}$ & $8.1 \pm 0.5$ & $7.8 \pm 0.5$ & & n. s. \\
\hline Conductivity $\left(\mu \mathrm{S} \mathrm{cm}^{-1}\right)$ & $338.8 \pm 72.8$ & $274.8 \pm 33.3$ & & n. s. \\
\hline $\operatorname{COD}\left(\mathrm{mgO}_{2_{\mathrm{KMnO}}} \mathrm{L}^{-1}\right)$ & $16.7 \pm 3.5$ & $29.6 \pm 4.5$ & 0.0 & 0.005 \\
\hline Orthophosphates; $\mathrm{P}^{-\mathrm{PO}_{4}{ }^{3-}\left(\mathrm{mg} \mathrm{L}^{-1}\right)}$ & $0.06 \pm 0.02$ & $0.092 \pm 0.033$ & 2.0 & 0.01 \\
\hline Total phosphorus (mg P L ${ }^{-1}$ ) & $0.39 \pm 0.045$ & $0.47 \pm 0.097$ & & n. s. \\
\hline Nitrates; $\mathrm{N}^{-\mathrm{NO}_{3}}{ }^{-}\left(\mathrm{mg} \mathrm{L}^{-1}\right)$ & $0.08 \pm 0.03$ & $0.123 \pm 0.047$ & & n. s. \\
\hline Ammonia; $\mathrm{N}-\mathrm{NH}_{4}{ }^{+}\left(\mathrm{mg} \mathrm{L}^{-1}\right)$ & $0.089 \pm 0.066$ & $0.118 \pm 0.102$ & & n. s. \\
\hline Total nitrogen (mg N L-1) & $0.81 \pm 0.17$ & $1.47 \pm 0.66$ & & n. s. \\
\hline $\mathrm{Chl} a\left(\mu \mathrm{g} \mathrm{L}^{-1}\right)$ & $25.6 \pm 9.9$ & $53.3 \pm 30.7$ & 2.0 & 0.01 \\
\hline POM (mg AFDM L-1) & $2.638 \pm 1.239$ & $0.717 \pm 0.770$ & & n. s. \\
\hline
\end{tabular}

HQ30d) and conductivity (Hach sensION5). Transparency (SD) was assessed using a Secchi disc $(\varnothing 20 \mathrm{~cm})$. Turbidity (NTU, Nephelometric Turbidity Unit) was determined using a spectrophotometer $\mathrm{HACH}$ DR/2000. Parallel to zooplankton, samples for chemical water analyses were taken. Measurement procedures for other physico-chemical water properties were as shown in Špoljar et al. (2016).

\section{Data analysis}

None of the environmental and biocoenotic data showed a normal distribution, based on the Shapiro-Wilk's test, even after logarithmic $[\log 10(x+1)]$ transformation, so nonparametric analyses were applied. Differences among habitats and months did not show significant differences (Kruskal-Wallis test, $\mathrm{p}>$ 0.05). Thus, further analyses for the inter-annual differences for abiotic and biotic factors based on Mann-Whitney $U$ test and Spearman correlations were performed (Statistica 12). Differences of zooplankton assemblage were checked by
SIMPER analysis (PRIMER v6). Using the same analytical software, the multivariate analysis of similarities (ANOSIM) was used to identify significance of inter- annual changes in zooplankton abundance. ANOSIM generates a value of $\mathrm{R}$ ranging between -1 and +1 ; a value of zero indicates no difference among a set of samples (Clarke and Warwick, 2001). In both analyses the Bray-Curtis coefficient was used for computing (dis)similarities.

\section{RESULTS}

Short-term inter-annual changes during the summer period in the studied oxbow lake underwent substantial hydrological changes. Water level increased by over 2 meters and caused almost complete reduction of macrophyte coverage (Table 1). Also, turbidity, orthophosphates and phytoplankton biomass (expressed as chlorophyll $a$ concentration) significantly increased between 2012 and 2013 (Table 1). 
These hydrological changes were also reflected in zooplankton assemblage. Copepoda significantly increased their abundance at the higher water level $(r=0.60, p>$ 0.05 ), an increase from average ca. 30 to 400 ind. $\mathrm{L}^{-1}$ (Fig. 1; Mann-Whitney $U$ test, $p=0.005$ ).
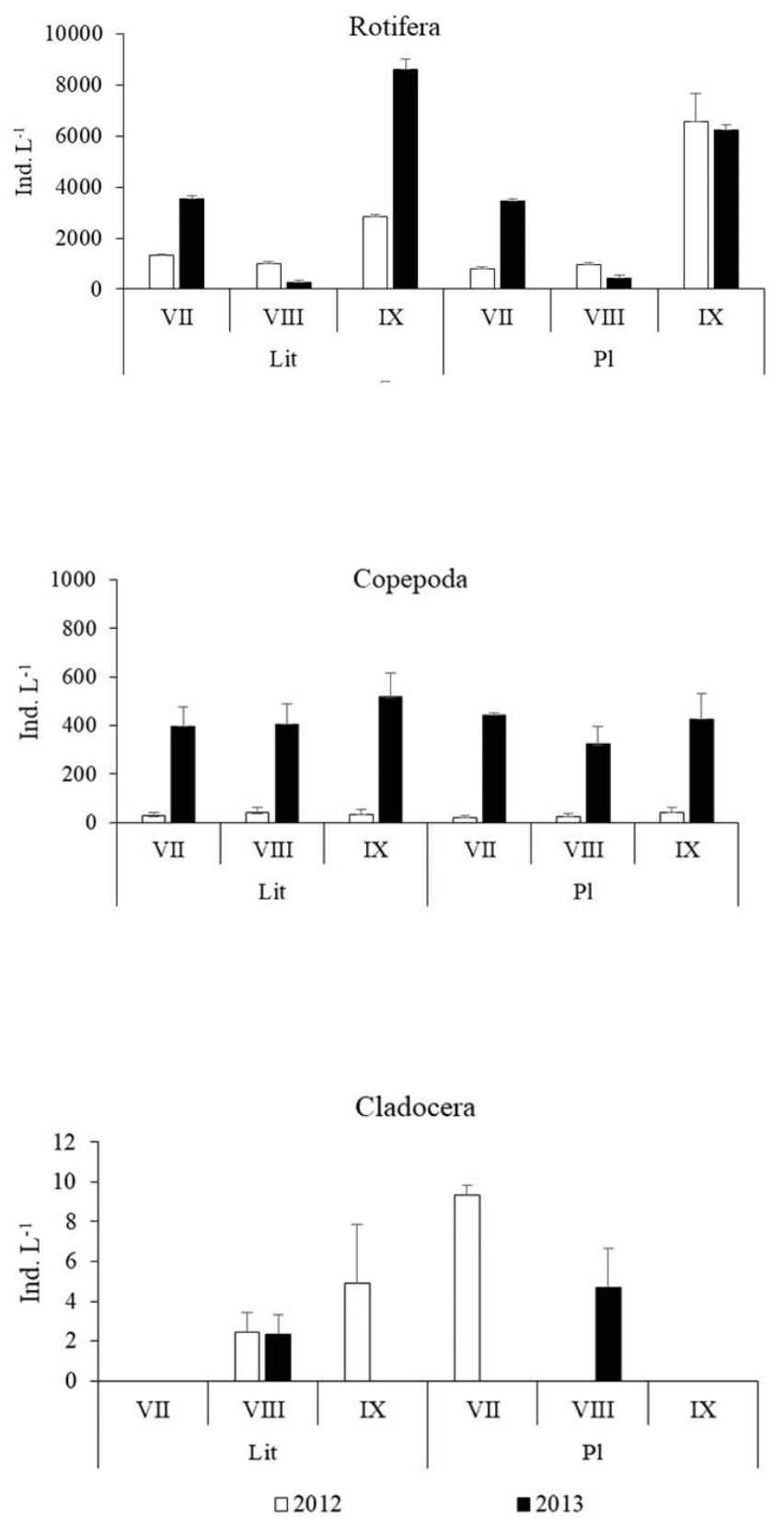

Fig 1. Inter-annual oscillations of Rotifera, Copepoda and Cladocera in the littoral (Lit) and pelagial (Pl) zone of Škrčev kut oxbow lake
Inter-annual oscillations in abundance for rotifers and cladocerans were not significant (Mann-Whitney $U$ test, $p>0.05)$, despite their notable differences. Rotifera were dominant in the zooplankton abundance and gained high abundance in 2012 (2247 \pm 2240 ind. $L^{-1}$ ) and 2013 $\left(3755 \pm 3259\right.$ ind $\left.L^{-1}\right)$, at the lower and higher water level, respectively (Fig. 1). Cladocera were present in both years by few specimens $\left(<10\right.$ ind $\left.\mathrm{L}^{-1}\right)$ and were almost completely absent in samples from 2013 at increased water level. Significant differences in life style forms were observed with increased water level, which negatively affected the abundance of littoral species (Mann-Whitney $U$ test, $p=$ 0.009). Results of SIMPER analysis indicated an average dissimilarity of $54 \%$ and main discriminator species, which developed abundant populations at the lower or higher water level (Table 2). Common littoral taxa, such as Bdelloidea or Lecane, were absent in 2013, at increased water level, while planktonic species proliferated. Nonmetric multi-dimensional scaling analysis based on zooplankton abundance suggested a significant difference in inter-annual summer zooplankton assemblage, $\mathrm{R}=$ 0.896, $p=0.002$ (Fig. 2).

Table 2. Average (Av.) abundances and contribution of taxa to dissimilarity in zooplankton assemblage affected by water level fluctuation (SIMPER analysis)

\begin{tabular}{lccc}
\hline & 2012 & 2013 & \multicolumn{2}{c}{ Contribution } \\
Species & Av. Abundance & Av. Abundance (\%) \\
\hline $\begin{array}{l}\text { Thermocyclops } \\
\text { oithonoides }\end{array}$ & 0 & 4.12 & 7.7 \\
$\begin{array}{l}\text { Bdelloidea } \\
\begin{array}{l}\text { Ascomorpha } \\
\text { ovalis }\end{array}\end{array}$ & 3.73 & 0 & 6.7 \\
$\begin{array}{l}\text { nauplii } \\
\begin{array}{l}\text { Trichocerca pusila } \\
\text { Lecane lunaris }\end{array}\end{array}$ & 0.28 & 2.01 & 6.5 \\
$\begin{array}{l}\text { Pompholyx } \\
\text { sulcata }\end{array}$ & 2.77 & 5.79 & 5.5 \\
\hline \hline
\end{tabular}

Common rach (Rutilus rutilus), stone moroko (Pseudorasbora parva) and pumpkinseed (Lepomis gibbosus) prevailed in fish abundance. Fish increased their biomass as the water level increased, but those changes were not significant (Mann-Whitney $U$ test, $p>0.05$; Fig. $3)$. Increased fish biomass and length negatively affected cladocerans, enabling a notable increase of rotifer and copepod abundance (Table 3). 
Table 3. Spearman rank coefficient ( $p<0.05)$ correlations among fish features and abundances of main zooplankton groups

Abundance (ind. $\mathrm{L}^{-1}$ )

Rotifera Cladocera Copepoda

\begin{tabular}{llll}
\hline Fish biomass $(\mathrm{g})$ & 0.62 & -0.75 & 0.58 \\
Fish total lenght $(\mathrm{cm})$ & 0.62 & -0.75 & 0.58 \\
\hline \hline
\end{tabular}

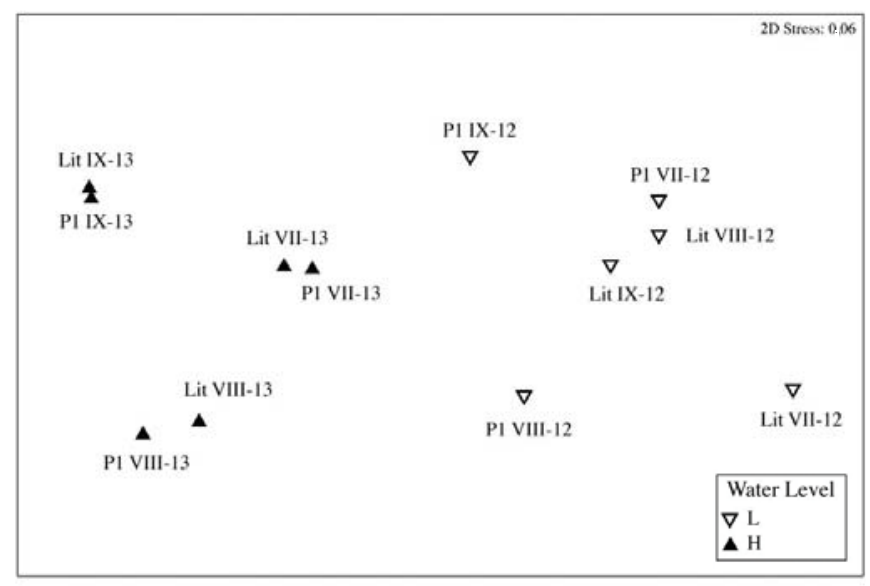

Fig 2. Non-metric multi-dimensional scaling (NMDS) of zooplankton segregation related to water level oscillations (L- low water level in 2012, H - high water level in 2013) in Škrčev kut oxbow lake

Fish biomass

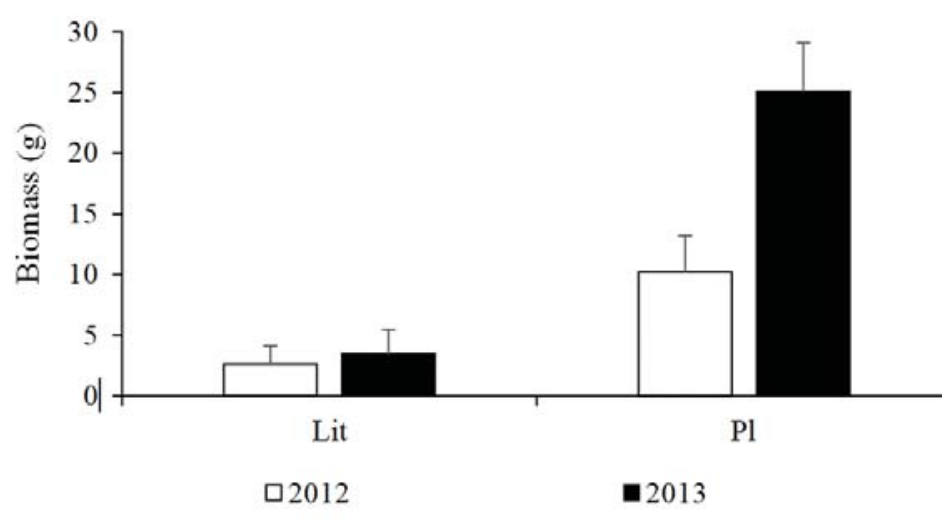

Fig 3. Inter-annual oscillations of fish biomass in Škrčev kut oxbow lake

\section{DISCUSSION}

The results of our study demonstrate that hydrological variability, even in a short year by year timescale, can strongly affect biocoenosis and ecosystem functioning of shallow lakes. A high amount of precipitation during the spring of 2013 caused increased water level in the Škrčev kut oxbow, and thus significant alterations of abiotic and biotic factors in the consecutive inter-annual summer survey. The floating-leaved waterlilies were dominant stand during the low water level in 2012, and almost vanished with increased water level in 2013. Macrophyte loss probably led to frequent resuspensions and internal nutrient loads reflected in increased phytoplankton biomass and turbidity. The results suggest that the increase of the water level diminished light availability and suppressed macrophyte growth. During that short period of comparison, zooplankton assemblage was strongly impacted by the appearance or disappearance of certain taxa, tremendous peaks and drops of their populations, likely connected with the change of habitats and food resources.

Water level fluctuations could cause extreme habitat conditions due to flooding and high precipitations (Galir Balkić et al., 2017) or drought (Kuczyńska-Kippen et al., 2013). Anoxia and metal accumulations in the sediment appear frequently during the low water level (Kovačević et al., 2007; Scheffer and van Ness, 2007). High water level often deteriorates habitats for littoral zooplankton and fish spawning and increases light attenuation (Leira and Cantonati, 2008). Geraldes and Boavida (2017) found the highest values of total phosphorus, soluble reactive phosphorus, nitrate, water colour and chlorophyll $a$ during the minimum level phase. Opposite findings arose from our study, with higher turbidity, nutrients, phytoplankton biomass and dissolved organic matter during the high water level. Results of our study indicate water level fluctuation as the main driver for the shift from floatingleaved macrophye dominant lake during the low water level into phytoplankton dominated state during the high water level. Opposite findings were exposed by O'Farrell et al. (2011) in a floodplain lake, Laguna Grande in Natural Reserve Otamendi (Argentina): the shift from free-floating macrophytes domination in the high water phase to phytoplankton dominant state with Cyanobacteria blooms in the low water phase.

It was assumed that water level fluctuations coupled with bottom-up and top-down effects shaped zooplankton assemblage in Škrčev kut oxbow, as similarly confirmed for cladocerans in Lake Arancio, southwest Sicily, Italy (NaselliFlores and Barone, 1997). Zooplankton in the studied oxbow was marked by an increase of rotifers and copepods during the high water column, confirming these groups as resilient and less sensitive organisms to the variation in hydrological regime. It is well known that among the metazooplankton, rotifers are the most abundant group in river-floodplain lakes (Galir Balkić et al., 2017) and shallow lakes (Špoljar et al., 2011; 2016). Rotifers as $r$-strategist organisms, with a short generation time and abundant offspring (Wallace et 
al., 2006), developed numerous populations during both phases, low and high water level. Also, rotifers are not the first fish "target" (González Sagrario et al., 2009). Littoral species of rotifers (bdelloids, Lecane) developed markedly more numerous populations during the low water level, due to macrophytes presence as their common habitats (Špoljar et al., 2012). Succession of the planktonic species was probably caused by competition for detritus and algae in the environment plentiful with food resources (Wallace et al., 2006). Cladocerans were present in both years with Bosmina longirostris and were completely exterminated, probably due to extended fish predation, which is in accordance with recent studies (González Sagrario et al., 2009; Špoljar et al., 2016). Copepod assemblage was significantly modified in transition from the low to the high water regime. Namely, copepods are quick in response to water oscillations and to fish, as visual predators.

Moreover, higher turbidity at higher water level and their abundant populations probably hindered fish efficiency (Estlander et al., 2009; Špoljar et al., 2016).

It was presumed that at the higher water level, resuspended nutrients, due to macrophyte absence, affected positively phytoplankton biomass and successively enhanced zooplankton growth, and thus productivity of the entire oxbow biocoenosis, including fish. Beside food resources, permanent inundation and sufficient oxygen concentration enabled the increase of fish biomass at the higher water level and these results are in accordance with those reported by Naselli-Flores and Barone (1997).

Our study showed that even in a short timescale effects of water level fluctuations impacted significantly biotic interactions, environmental conditions and ecosystem functioning. Further studies should focus on more frequent sampling and comprise the entire biocoenosis pattern.

\section{Sažetak}

\section{UTJECAJ FLUKTUACIJE RAZINE VODE NA} SASTAV ZOOPLANKTONA PLITKOG JEZERA

Promjene u okolišu pod utjecajem su globalnih klimatskih promjena i snažno utječu na ekosustav plitkih jezera te narušavaju relevantne parametre, na primjer biološku raznolikost i prozirnost vode. Tijekom ljeta 2012. i 2013. provedeno je istraživanje zooplanktona u mrtvaji Škrčev put, u porječju rijeke Krapine (SZ Hrvatska, Europa). Cilj istraživanja bio je utvrditi utjecaj promjena hidrološkog režima u kratkom vremenskom razdoblju na uvjete okoliša, pokrovnost makrofitima, strukturu zooplanktona i riba $\mathrm{u}$ plitkom jezeru umjerenog područja. U razdoblju od godinu dana razina vode se podigla za 2 metra, što je uzrokovalo značajno smanjenje prisutnosti plutajućih makrofita (npr. Nuphar lutea), dok su vrijednosti prozirnosti, ortofosfata i klorofila a porasle. Ovi izmijenjeni ekološki uvjeti odrazili su se na promjenu, od jezera pokrivenog plutajućim makrofitima tijekom niske razine vode u jezero s dominacijom fitoplanktona tijekom visoke razine vode. Ova promjena značajno se odrazila na promjene u sastavu zooplanktona. Rezultati ukazuju da su ribe utjecale na smanjenje populacije rašljoticalaca, dok su populacije kolnjaka i veslonožaca zadržale visoku brojnost, odnosno nisu direktno izložene predaciji riba. Zaključno, planktonska zajednica je, čak i kratkoročno, podložna promjenama uslijed izmijenjenih okolišnih uvjeta.

Ključne riječi: Rotifera, Cladocera, Copepoda, ribe, makrofiti plutajućih listova, riječno jezero (mrtvaja)

\section{REFERENCES}

Amoros, C. (1984): Crustaces cladoceres. Bulletin Mensuel de la Société Linnéenne de Lyon, 3, 4, 1-63.

Balayla, D., Lauridsen, T. L., Søndergaard, M., Jeppesen, E. (2010): Larger zooplankton in Danish lakes after cold winters: are winter fish kills of importance? Hydrobiologia, 646, 159-172.

Beklioglu, M., Altinayar, G., Tan, C.O. (2006): Water level control over submerged macrophyte development in five shallow lakes of Mediterranean Turkey. Archive für Hydrobiology, 166, 4, 535-556.

Beklioglu, M., Meerfhoff, M., Søndergaard, M., Jeppesen, E. (2011): Eutrophication and restoration of shallow lakes from a old temperate to a warm mediterranean and a (sub) tropical climate. pp. 91-129. In: Ansari, A. A., Singh, G. S., Lanza, R., Rast, W. (eds), Eutrophication: Causes, Consequences and Control. $1^{\text {St }}$ edn. Springer, Dordrecht, The Netherlands. 394.

Beklioglu, M., Romo, S., Kagalou, I., Quintana, X., Bécares, E. (2007): State of the art in the functioning of shallow Mediterranean lakes: workshop conclusions. Hydrobiologia, 584, 317-326.

Brucet, S., Boix, D., Nathansen, L. W., Quintana, X. D., Jensen, E., Balayla, D., Meerhoff, M., Jeppesen, E. (2010): Effects of Temperature, Salinity and Fish in Structuring the macroinvertebrate Community in Shallow Lakes: Implications for Effects of Climate Change. Plos One, 7, 2 e30877, doi:10.1371/journal.pone.0030877.

Castro, B. B., Marques, S. M., Goncalves, F. (2007): Habitat selection and diel distribution of the crustacean zooplankton from a shallow Mediterranean lake during the turbid and clear water phases. Freshwater Biology, 52, 421-433.

Clarke, K. R., Warwick, R. M. (2001): Changes in Marine Communities: an Approach to Statistical Analysis and Interpretation. PRIMER-E, Plymouth, UK.

Coops, H., Beklioglu, M., Crisman, T. L. (2003): The Role of Water-Level Fluctuations in Shallow Lake Ecosystems- 
Workshop Conclusions. Hydrobiologia, 506, 23-27. Coops, H., Hosper, H. S. (2002): Water-Level Menagement as a Tool for the Restoration of Shallow Lakes in the Netherlands. Lake and Reservoir Management, 18, 4, 293-298.

Coppens, J., Özen, A., Tavşanoğlu, Ü. N., Erdoğan, Ş., Levi, E. E., Yozgatlıgil, C., Jeppesen, E., Beklioğlu, M. (2016): Impact of alternating wet and dry periods on long-term seasonal phosphorus and nitrogen budgets of two shallow Mediterranean lakes. Science of Total Environment, 563-564, 456-467.

Echaniz, S. A., Vignatti, A. M. (2017): The zooplankton of the shallow lakes of the semi-arid region of southern South America. Annales de Limnologie - International Journal of Limnology, 53, 345-360.

Einsle, U. (1993): Crustacea, Copepoda, Calanoida und Cyclopoida. pp 1-208. In: Schwoerbel, J., Zwick, P. (eds), Süsswasserfauna von Mitteleuropa. Gustav Fischer Verlag, Berlin, Germany. 209.

Estlander, S., Nurminen, L., Olin, M., Vinni, M., Horppila, J. (2009): Seasonal fluctuations in macrophyte cover and water transparency of four brown-water lakes: implications for crustacean zooplankton in littoral and pelagic habitats. Hydrobiologia, 620, 109-120.

Galir Balkić, A., Ternjej, I., Špoljar, M. (2017): Hydrology driven changes in the rotifer trophic structure and the implications for food web interactions. Ecohydrology, 11, (1), e1917.

Geraldes, A. M., Boavida, M. J. (2007): Zooplankton assemblages in two reservoirs: one subjected to accentuated water level fluctuations, the other with more stable water levels. Aquatic Ecology, 41, 2, 273-284.

González Sagrario, M. Á., Balseiro, E., Ituarte, R., Spivak, E. (2009): Macrophytes as refuge or risky area for zooplankton: a balance set by littoral predacious macroinvertebrates. Freshwater Biology, 54, 1042-1053.

Iglesias, C., Mazzeo, N., Meerhoff, M., Lacerot, G., Clemente, J., Scasso, F., Kruk, C., Goyenola, G., Garcia, J., Amsinck, S. L., Paggi, J., Jose, C., de Paggi, S., Jeppesen, E. (2011): High predation is the key factor for dominance of smallbodied zooplankton in warm lakes - evidence from lakes, fish enclosures and surface sediment. Hydrobiologia, 667, 133-147.

Kalafatić, M., Kovačević, G., Zupan, I., Franjević, D. (2003): Effect of repeated UV- irradiation on Hydra oligatis Pallas. Periodicum biologorum, 105, 2, 171-175.

Kovačević, G., Želježić, D., Horvatin, K., Kalafatić, M. (2007): Morphological features and comet assay of green and brown hydra treated with aluminium. Symbiosis, 44, 1, 145-152.

Kuczyńska-Kippen, N. (2001): Diurnal vertical distribution of rotifers (Rotifera) in the Chara zone of Budzyńskie Lake, Poland. Hydrobiologia, 446, 447, 195-201.

Kuczyńska-Kippen, N., Basińska, A. M.,Świdnicki, K. (2013):
Specificity of zooplankton distribution in meteorite crater ponds (Morasko, Poland). Knowledge and Management of Aquatic Ecosystems, 409.

Leira, M., Cantonati, M. (2008): Effects of water-level fluctuations on lakes: an annotated bibliography. Hydrobiologia, 613, 171-184.

Meerhoff, M., Iglesias, C., De Mello, F. T., Clemente, J. M., Jensen, E., Lauridsen, T. L., Jeppesen, E. (2007): Effects of habitat complexity on community structure and predator avoidance behaviour of littoral zooplankton in temperate versus subtropical shallow lakes. Freshwater Biology, 52, 1009-1021.

Naselli-Flores, L., Barone, R. (1997): Importance of waterlevel fluctuation on population dynamics of cladocerans in a hypertrophic reservoir (Lake Arancio, south-west Sicily, Italy). Hydrobiologia, 360, 223-232. In: Brancelj, A., De Meester, L., Spaak, P. (eds), Cladocera: The Biology of Model Organisms. Kluwer Academic Publishers, Belgium.

O'Farrell, I., Izaguirre, I., Chaparro, G., Unrein, F., Sinistro, R., Pizarro, H., Rodriguez, P., de Tezanos Pinto, P., Lombardo, R., Tell, G. (2011): Water level as the main driver of the alternation between a free-floating plant and a phytoplankton dominated state: a long-term study in a floodplain lake. Aquatic Sciences, 73, 275-287.

Özen, A., Karapinar, B., Kucuk, I., Jeppesen, E., Beklioglu, M. (2010): Drought-induced changes in nutrient concentrations and retention in two shallow Mediterranean lakes subjected to different degrees of management. Hydrobiologia, 646, 61-72.

Portielje, R., Roijackers, R. M. M. (1995): Primary succession of aquatic macrophytes in experimental ditches in relation to nutrient input. Aquatic Botany, 50, 2, 127-140.

Scheffer, M., Hosper, S. H., Meijer, M. L., Moss, B., Jeppesen, E. (1993): Alternative equilibria in shallow lakes. Trends in Ecology and Evolution, 8, 8, 275-279.

Scheffer, M., van Ness, E. H. (2007): Shallow lakes theory revisited: various alternative regimes driven by climate, nutrients, depth and lake size. Hydrobiologia, 584, 455-466.

Simões, N. R., Lansac-Tôha, F. A., Velho, L. F. M., Bonecker, C. C. (2012): Intra and inter- annual structure of zooplankton communities in floodplain lakes: a long-term ecological research study. Revista de Biolog a Tropical, 60, 4, 1819-1836.

Starling, F., Lazzaro, X., Cavalcanti, C., Moreira, R. (2002): Contribution of omnivorous tilapia to eutrophication of a shallow tropical reservoir: evidence from a fish kill. Freshwater Biology, 47, 2443-2452.

Špoljar, M., Dražina, T., Habdija, I., Meseljević, M., Grčić, Z. (2011): Contrasting zoplankton assemblages in two oxbow lakes with low transparencies and narrow emergant macrophyte belts (Krapina River, Croatia). International Review of Hydrobiology, 96, 175-190.

Špoljar, M., Dražina, T., Šargač, J., Kralj-Borojević, K., Žutinić, 
P. (2012): Submerged macrophytes as a habitat for zooplankton development in two reservoirs of a flowthrough system (Papuk Nature Park, Croatia). Annales de Limnologie - International Journal of Limnology, 48, 161-175.

Špoljar, M., Tomljanović, T., Dražina, T., Lajtner, J., Štulec, H., Matulić, D., Fressl, J. (2016): Zooplankton structure in two interconnected ponds: similarities and differences. Croatian Journal of Fisheries, 74, 1, 6-13.
Streble, H., Krauter, D. (2006): Das Leben im Wassertropfen - Mikroflora und Mikrofauna des Süßwassers. KOSMOS Verlag, Stuttgart, Germany. 432.

Voigt, M., Koste, W. (1978): Die Rädertiere Mitteleuropas. Gebrüder Borntraeger, Berlin, Stuttgart, Germany. 673.

Wallace, R. L., Snell, T. W., Ricci, C., Nogrady, T. (2006): Rotifera. Vol.1. Biology, Ecology and Systematics ( $2^{\text {nd }}$ edn). Kenobi Productions, Ghent, Belgium. 290. 